\title{
RESPON GURU DAN SISWA TERHADAP PENGGUNAAN LKS BERBASIS MULTIPLE INTELLEGENCES
}

\author{
Dian Ika Kusumaningtyas ${ }^{1}$, Maharani Putri Kumalasani ${ }^{2}$ \\ Program Studi Pendidikan Guru SD, Universitas Muhammadiyah Malang, Indonesia \\ daianika@gmail.com,maharaniputri@gmail.com
}

\begin{abstract}
Abstrak
Pembelajaran hendaknya dapat memfasilitasi dalam memaksimalkan kecerdasan yang dimiliki oleh siswa. Untuk memaksimalkannya dibutuhkan bahan ajar yang dapat mendukung siswa dalam melakukan kegiatan. Buku siswa tidak cukup untuk memaksimalkan kecerdasan sehingga dibutuhkan bahan ajar penunjang misalnya LKS dengan berbasis Multiple Intellegences. Penelitian ini bertujuan untuk mengetahui gambaran respon guru dan siswa terhadap penggunaan LKS berbasis multiple intellegences. Diharapkan setelah mengetahui respon tersebut bisa menjadi bahan masukan dalam pengembangan bahan ajar berbasis multiple intellegences, khususnya pada LKS. Metode yang digunakan ialah penelitian kualitatif deskriptif. Pengumpulan data dilakukan dengan observasi, dokumentasi, dan angket. Hasil penelitian ini ialah deskripsi terkait respon guru dan respon siswa yaitu siswa senang karena LKS mudah dipahami, mengarahkan siswa lebih aktif , menarik, kegiatan lebih bervariasi serta mendukung memaksimalkan kecerdasan dengan memanfaatkan lingkungan sebagai sumber belajar siswa.
\end{abstract}

Kata kunci: Guru dan Siswa, LKS, Multiple Intellegences.

\begin{abstract}
Learning should be able to facilitate in maximizing the intelligence possessed by students. To maximize it requires teaching materials that can support students in carrying out activities. Student books are not enough to maximize intelligence so that supporting supporting materials such as LKS with multiple intelligence are needed. This study aims to determine the description of teacher and student responses to the use of multiple intelligence based LKS. The method used is descriptive qualitative research. Data collection is done by observation, documentation, and questionnaire. The results of this study are descriptions related to teacher responses and student responses, namely students are happy because LKS is easy to understand, directs students more active, interesting, more varied activities and supports maximizing intelligence by utilizing the environment as a learning resource for student.
\end{abstract}

Keywords: Teachers and Students, LKS, Multiple Intellegences 


\section{PENDAHULUAN}

Pembelajaran tematik yang dilakukan di Sekolah Dasar sudah seharusnya terus dilakukan pengembangan untuk meningkatkan kualitas kegiatan pembelajaran maupun luaran dari proses pembelajaran itu sendiri. Subjek yang terlibat secara langsung dalam proses pembelajaran yaitu guru dan siswa. Pembelajaran yang baik, tidak hanya didominasi oleh peran aktif guru, tetapi siswa yang lebih dituntut aktif dan terlibat langsung. Guru tidak hanya melakukan ceramah tetapi diharapkan dapat lebih mengeksplorasi kegiatan pembelajaran. Hal tersebut perlu dilakukan untuk memaksimalkan ketercapaian kemampuan siswa baik dari aspek kognitif, psikomotor, dan afektif. Selain ketiga aspek tersebut, memaksimalkan kecerdasan yang dimiliki siswa juga menjadi hal penting dalam pembelajaran.

Kecerdasan merupakan kemampuan seseorang dalam memahami, melakukan inovasi, berpikir rasional dan memberikan solusi pada berbagai situasi. Gardner (1993) mendefinisikan kecerdasan sebagai kemampuan untuk menyelesaikan masalah atau menciptakan produk berharga dalam lingkungan budaya dan masyarakat. Kecerdasan yang dimiliki oleh seseorang memiliki perbedaan yang dilihatkan pada hasil tes IQ. Gardner (1993) menjelaskan bahwa Binet mendefinisikan kecerdasan dengan sangat sempit, yaitu dengan melakukan tes kecerdasan atau disebut IQ (Intelligence Question), yang menunjukkan tingkatan kecerdasan pada rentang yang telah ditentukan. Hal ini yang dapat mengklasifikasikan seseorang memiliki kemampuan tinggi, sedang, dan kurang. Kecerdasan sangat penting dimiliki oleh setiap orang dalam setiap kegiatan yang dilakukan, agar kegiatan tersebut dapat dilaksanakan dengan baik. Jika kecerdasan selalu diasah dalam kegiatan yang dilakukan, maka akan tercipta Sumber Daya Manusia (SDM) yang berkualitas.

Siswa Sekolah Dasar (SD) yang merupakan generasi penerus bangsa, diharapkan kelak menjadi seseorang yang memiliki SDM yang berkualitas, agar nantinya mereka dapat meneruskan cita-cita bangsa. Kecerdasan yang mereka miliki harus diasah sejak dini agar kemampuan berpikir mereka dapat berkembang. Aktivitas yang dapat mengasah kecerdasan siswa dapat dilakukan dalam proses pembelajaran tematik dengan ditunjang buku siswa. Akan tetapi, buku siswa itu sendiri merupakan sumber belajar minimal dan dimungkinkan untuk menggunakan bahan ajar lain dalam pembelajaran tematik.

Selain buku siswa, guru dapat menggunakan bahan ajar lain yang relevan untuk mengembangkan dan memaksimalkan kecerdasan yang dimiliki siswa. Salah satu jenis bahan ajar yang dapat digunakan guru yaitu LKS (Lembar Kegiatan Siswa). Menurut Ernawati, Ibrahim, \& Afiif (2017) LKS merupakan sekumpulan kegiatan mendasar yang harus dilakukan siswa untuk memaksimalkan pemahamannya serta pencapaian hasil belajar sesuai indikator pembelajaran. LKS dapat digunakan guru untuk lebih mengembangkan kegiatan siswa dalam pembelajaran. Selain guru menggunakan buku guru dan buku siswa, LKS dapat digunakan sebagai bahan ajar penunjang.

LKS yang fokus untuk memaksimalkan kecerdasan siswa yaitu LKS yang berbasis Multiple Intellegences. Multiple Intellegences adalah cara seseorang untuk berpikir dan bertindak dalam memecahkan masalah menggunakan kecerdasan-kecerdasan yang dimilikinya. Kecerdasan tersebut akan bekerja bersama dalam kehidupan manusia. Gardner (1993) mengelompokkan delapan kategori kecerdasan antara lain kecerdasan visual/spasial, kecerdasan 
verbal/linguistik, kecerdasan logis matematis, kecerdasan musikal/ritmik, kecerdasan kinestetik, kecerdasan interpersonal, kecerdasan intrapersonal, dan kecerdasan naturalis. Gardner memiliki pandangan umum mengenai kemampuan seseorang yang melampaui batas. Dia memberikan sarana pemetaan rentang luas mengenai kemampuan manusia dengan mengelompokkan kapasitas mereka dalam delapan kecerdasan, karena masing-masing kecerdasan dianggap sama pentingnya untuk kehidupan manusia. Teori ini dikenal dengan Multiple Intellegences yang berkembang sampai saat ini. Pengembangan kedelapan kecerdasan tersebut dapat diasah melalui kegiatan belajar siswa yang dilakukan di sekolah, di rumah dan di masyarakat tempat mereka tinggal.

Kegiatan belajar siswa di sekolah dapat dikembangkan melalui penggunaan LKS berbasis Multiple Intellegences. Kegiatan yang ada pada LKS dapat menjadi salah satu sarana untuk mengembangkan berbagai kecerdasan siswa. Tidak hanya terbatas pada satu kecerdasan, akan tetapi dapat mengembangkan semua kecerdasan yang dimiliki. Oleh karena itu, diharapkan dengan adanya LKS akan memaksimalkan kegiatan yang dilakukan siswa serta mengembangkan berbagai kecerdasan yang dimilikinya.

Berdasarkan pemaparan diatas, maka peneliti tertarik untuk memaparkan lebih lanjut terkait respon guru dan siswa saat menggunakan LKS berbasis Multiple Intellegences. Dengan mengetahui respon guru dan siswa, maka dapat memberikan gambaran bagaimana kelebihan dan kekurangan penggunaan LKS Multiple Intellegences dalam proses pembelajaran. Tujuan penelitian ini dilakukan yaitu untuk mengetahui respon guru dan siswa terhadap penggunaan LKS berbasis Multiple Intellegences.

\section{METODE PENELITIAN}

Penelitian ini menggunakan jenis penelitian kualitatif deskriptif. Penelitian dilakukan pada bulan Oktober sampai November pada siswa kelas IV SD sejumlah 19 siswa. Instrumen yang digunakan yaitu lembar observasi, lembar dokumentasi, serta lembar angket. Prosedur pengumpulan data dilakukan dengan observasi, dokumentasi, dan angket. Observasi dilakukan ketika penggunaan dari LKS dilakukan dalam pembelajaran di kelas. Selain itu dilakukan pula dokumentasi sebagai bukti dan data pendukung dari pelaksanaan kegiatan. Setelah dilakukan ujicoba LKS lalu diberikan angket untuk mengetahui gambaran dari respon pengguna LKS yaitu respon guru dan siswa. Setelah data terkumpul, kemudian dilakukan analisis data model Miles dan Huberman, yang terdiri dari 3 tahapan yaitu reduksi data, display data, dan verifikasi data.

\section{HASIL DAN PEMBAHASAN}

Berikut ini akan dipaparkan hasil penelitian yang diperoleh terkait LKS berbasis Multiple Intellegences. Respon Guru, pada saat penggunaan LKS berbasis Multiple Intellegences, dapat diketahui bahwa guru turut serta dalam membelajarkan siswa. Guru kelas IV menyampaikan bahwa secara umum LKS ini mudah dipahami dan digunakan. LKS sudah sesuai untuk mendukung pelaksanaan pembelajaran secara tematik dan sesuai dengan K13 sehingga dapat digunakan sebagai penunjang buku siswa. Selain itu, kegiatan pada LKS sudah mengarahkan siswa untuk lebih aktif dalam pembelajaran terutama dalam upaya memaksimalkan kecerdasan yang dimilikinya. Kegiatan yang dilakukan juga sudah mengarahkan siswa untuk dapat berinteraksi dengan lingkungan di 
sekitarnya baik itu dengan teman maupun lingkungan belajarnya. Akan tetapi, terdapat beberapa saran dan masukan yang disampaikan yaitu terkait penggunaan bahasa dan penulisan istilah yang sebaiknya bisa lebih diperjelas lagi.

Respon siswa setelah menggunakan LKS berbasis Multiple Intellegences yaitu mereka senang dan menyukai pembelajaran yang dilakukan. Hal tersebut dikarenakan tampilan LKS yang menarik dan juga mudah dipahami. LKS ini memang didesain dengan penggunaan beberapa simbol dan warna sehingga lebih menarik bagi siswa. Siswa juga mudah melakukan kegiatan karena langkahlangkah dari setiap kegiatan sudah tertulis dengan jelas pada LKS tersebut. Siswa lebih bersemangat belajar karena kegiatan yang dilakukan lebih bervariasi. Misalnya, siswa tidak hanya ditugaskan untuk mengerjakan tugas secara individu tetapi juga terdapat tugas kelompok. Tugas yang diselesaikan pun beragam, mulai dari menempel gambar lalu mendeskripsikan, melakukan wawancara dengan teman, bermain alat musik dari benda di sekitar dan masih banyak kegiatan lainnya. Akan tetapi, sama halnya dengan guru, siswa juga menyarankan untuk lebih memperhatikan penulisan bahasa yang kurang tepat agar penggunaan bahasa pada LKS menjadi lebih baik. Arafah dkk (2012) mengatakan bahwa LKS dikatakan valid dapat ditinjau dari penilaian pakar dengan skor maksimum pada tata urutan pelajaran yang sesuai dengan tingkat kemampuan siswa dan sumber bacaan yang sesuai dengan jangkauan keterbacaan siswa.

Berdasarkan pemaparan hasil penelitian dalam diketahui bahwa secara umum penggunaan LKS berbasis Multiple Intellegences mendapat respon yang baik dari guru maupun siswa. Dari respon guru dapat diketahui bahwa kegiatan pembelajaran yang terdapat pada LKS relevan dengan kercapaian Kompetensi Dasar yang terdapat pada K13. Selain itu LKS sudah menunjang pelaksanaan pembelajaran secara tematik. Hal tersebut dapat diketahui dari kegiatan yang dilakukan mengarahkan siswa untuk lebih aktif dan memperoleh pembelajaran yang bermakna karena siswa terlibat langsung dalam pembelajaran. Saprahayuningsih (2010) menyatakan bahwa proses pembelajaran akan mampu meningkatkan kecerdasan dan kreativitas apabila siswa diberikan kesempatan untuk berpikir tidak hanya secara konvergen tetapi juga divergen, yakni dengan peningkatan indikator kemampuan berpikir kreatif. Kondisi tersebut sejalan dengan pernyataan Rofiah (2016) tentang pengembangan pembelajaran dengan berfokus pada Multiple Intellegences . Kecerdasan pada siswa dapat diasah dengan pengayaan, dukungan dan pengajaran bagi siswa. Kegiatan siswa secara aktif dalam pembelajaran tidak lepas dari adanya interaksi dengan siswa yang lain. Hal tersebut juga dapat memperkuat kecerdasan interpersonal siswa. Kecerdasan ini menyukai dan menikmati bekerja secara berkelompok, belajar sambil berinteraksi dan bekerja sama (Armstrong, 2009).

Dari respon siswa diketahui pula bahwa siswa lebih mudah memahami dan bersemangat dalam belajar saat menggunakan LKS. Hal tersebut dapat diketahui dari beragamnya kegiatan yang dilakukan seperti melakukan wawancara, menempel gambar, bermain alat musik dan lain sebagainya. Selain itu pemanfaatan lingkungan sekitar siswa seperti benda-benda dan budaya di sekitar menjadikan pembelajaran lebih bermakna. Hal ini sesuai dengan pernyataan dari Prastowo dalam Unp (2012) terkait fungsi LKS sebagai salah satu bahan ajar yaitu salah satunya menyediakan bahan ajar sesuai dengan kebutuhan siswa di lapangan, sesuai dengan karakteristik dan lingkungan di sekitar siswa dengan berdasarkan pada kurikulum yang berlaku. 
Berdasarkan saran dan masukan dari respon guru maupun siswa terkait penggunaan dan penulisan bahasa dalam LKS, maka perlu adanya perbaikan agar penulisannya dapat lebih baik. Hal tersebut sesuai dengan salah satu prinsip bahan ajar yang baik yaitu prinsip konsistensi artinya keajegan. Konsistensi diperlukan dalam mengembangkan bahan ajar sehingga apa yang ditulis dapat dipahami dengan baik (Antara, Kosa, \& Dan, n.d.)

\section{KESIMPULAN DAN SARAN}

Hasil penelitian tentang respon guru dan siswa setelah menggunakan LKS berbasis multiple intellegences mendapatkan hasil bahwa guru menyampaikan LKS ini mudah digunakan dalam pembelajaran, LKS sesuai dan mendukung dalam proses pembelajaran, serta mengarahkan siswa lebih aktif dalam proses pembelajaran. Respon siswa setelah menggunakan LKS didapatkan bahwa siswa senang dalam pembelajaran pada saat menggunakan LKS karena LKS menarik, mudah dipahami, kegiatannya bervariatif sehingga membuat siswa bersemangat dalam belajar. Guru dapat membuat LKS dalam bentuk lain yang dapat memotivasi siswa untuk belajar.

\section{DAFTAR RUJUKAN}

Antara, H., Kosa, P., \& Dan, K. (n.d.). Issn : 2337-3253, 7, 1-8.

Arafah, S. F., B. Priyono, \& S. Ridlo. 2012. Pengembangan LKS Berbasis Berpikir

Kritis pada Materi Animalia. Unnes Journal of Biology Education, 1(1): 75-81.

Armstrong, T. (2009). Intelligences multiple in the classroom. Educational Research (Vol. 18). https://doi.org/10.3102/0013189X018008004

Ernawati, A., Ibrahim, M. M., \& Afiif, A. (2017). Pengembangan Lembar Kerja Siswa Berbasis Multiple Intelligences Pada Pokok Bahasan Substansi Genetika Kelas Xii Ipa Sma Negeri 16 Makassar. Jurnal Biotek, 5(2), 1-18. Retrieved from http://journal.uinalauddin.ac.id/index.php/biotek/article/view/4276/3999

Gardner, H. (1993). H owar d Frames of Mind.

Rofiah, N. H. (2016). Urgensi pembelajaran terpadu dalam pembelajaran di sekolah dasar, 69-79.

Saprahayuningsih, S. 2010. Peningkatan Kecerdasan dan Kreativitas Siswa. Jurnal Kependidikan Dasar, 1(1) : 1-6.

Unp, F. (2012). Penggunaan Lembar Kerja Siswa Yang Dilengkapi Mind Map, $1(1), 30-34$. 